Journal of Southeast Asian

\title{
To Make A Return
}

Mai Der Vang

maidervaj@gmail.com

Follow this and additional works at: https://docs.lib.purdue.edu/jsaaea

Part of the Asian American Studies Commons

\section{Recommended Citation}

Der Vang, Mai (2010) "To Make A Return," Journal of Southeast Asian American Education and Advancement: Vol. 5 : Iss. 1, Article 6.

DOI: $10.7771 / 2153-8999.1007$

Available at: https://docs.lib.purdue.edu/jsaaea/vol5/iss1/6

This document has been made available through Purdue e-Pubs, a service of the Purdue University Libraries. Please contact epubs@purdue.edu for additional information.

This is an Open Access journal. This means that it uses a funding model that does not charge readers or their institutions for access. Readers may freely read, download, copy, distribute, print, search, or link to the full texts of articles. This journal is covered under the CC BY-NC-ND license. 


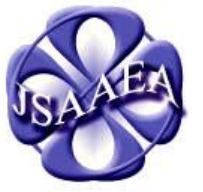

Volume 5 (2010)

\section{Journal of Southeast Asian American \\ Education \& Advancement}

WWW.JSAAEA.org
A peer-reviewed scholarly journal published by the National Association for the Education \& Advancement of Cambodian, Laotian, and Vietnamese Americans (NAFEA)

\section{To Make A Return}

\section{by \\ Mai Der Vang}

"In a way, we are nothing more-or less—than an encoded memory of our heritage."

- Eva Hoffman, Letters In Transit

You are born here,

someplace alien to your ancestral tongue.

Cars replace your two feet

on a spiraling superhighway.

Tract housing becomes a destination

on dizzy roads that look too much alike.

Your father. Your mother.

A young couple far from home

and anything familiar. Stretched

beyond sanity like hitting walls in a maze.

You go to public school,

where you are taught how pilgrims and Indians

ate together, how to pledge allegiance,

and become invisible by turning off your voice

like taking off a jacket.

Never getting the one you want

because of the jobs your parents do not have.

And what you learn on back-to-school night,

when your mother does not know how to

write your name on the chalkboard

of your fourth grade class.

You become jaded by senior year, swallowed by the language you can

hardly speak, and the assignments that

swarm inside your backpack.

In the midst of eight kids, you feel alone

because they will not let you be.

\footnotetext{
(c)

SOMERIGHISRESERVED Readers are free to copy, display, and distribute this article, as long as the work is attributed to the author(s) and the Journal of Southeast Asian American Education \& Advancement, it is distributed for noncommercial purposes only, and no alteration or transformation is made in the work. More details of this Creative Commons license are available at http://creativecommons.org/licenses/by-nc-nd/3.0/. All other uses must be approved by the author(s) or JSAAEA.
} 
You wake at 6AM on a Saturday morning to move couches before the shaman arrives.

There are chickens fussing in the backyard, and the neighbors might hear.

The night you come home late, your father burns his words into the cracks of the narrow driveway.

You move away from home, chart your course in a crowded landscape. The cup of freewill flowing to the rim, like the expensive red wine in your kitchen pantry. You pour wax from the candles next to the tub where you soak. No one to bang on the door while you sink in salts and yesterday's edition of The New York Times.

On the subway, you watch the high rises shield your sight beyond the city walls.

You wander the streets, yearning for the recognizable. How you almost cry at the sight of lemongrass in a stranger's yard. The old woman a few doors down whose embroidery looks like the neon cross-stitched fabric collecting dust in your mother's closet. Even the homeless vet who says he knows of your people because he fought in 'Nam.

You comb through books, magazines, journals to uncover scabs, peeling from the wounds left by a war your parents did not explain, except to say they had to run.

You shrug it off, and now, years after, you know the reason why your mother feared fireworks on Fourth of July. Why she keeps an old piece of clothing locked in a suitcase, the same one she wore the night they left Laos.

And your father, a man of tangled emotions who says he was only showing love the day he cursed you from the house. When all along you think the only war is the one inside you. 
Vang - To Make A Return

You return home.

To loathe something, but to need it.

Like the twisted red string your mother tied around your left wrist.

Its tainted mildew scent sometimes polluting, your skin, but never taking over its purpose.

Never forgetting to bring you back.

\section{About the Author}

Mai Der Vang is a Hmong-American writer/poet who lives in Fresno, CA in the United States. Poems of hers have been published in Paj Ntaub Voice. In September of 2009, she completed a residency at Hedgebrook, a program for women writers. She is also a member of the Hmong American Writers' Circle (HAWC) and currently serving on the editorial board for an upcoming Hmong literary anthology with HAWC for Heyday Books. 


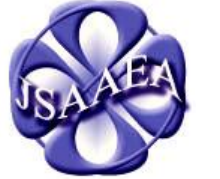

Journal of Southeast Asian American Education \& Advancement

Volume 5(2010)

WWW.JSAAEA.org
Editor

Dr. Wayne E. Wright

University of Texas, San Antonio

Associate Editors

Dr. Chhany Sak-Humphry

University of Hawaii

Dr. KimOanh Nguyen-Lam

California State University, Long Beach

Book Review Editor

Dr. Vichet Chhuon

University of Minnesota

Creative Works Editor

Bryan Thao Worra

Lao Assistance Center

\section{Special Advisor}

Gregory Green

Curator, Echols Collection on Southeast Asia, Cornell University Library

\section{Editorial Assistant}

Kathleen Langham

University of Texas, San Antonio
A peer-reviewed

scholarly journal published by the

National Association

for the Education \&

Advancement of

Cambodian, Laotian,

and Vietnamese

Americans (NAFEA)

Comments and questions for the editorial staff may be directed to jsaaea@ lists.sis.utsa.edu

\section{Editorial Review Board}

\author{
Dr. Carl L. Bankston III \\ Tulane University \\ Dr. Phala Chea \\ Lowell Public Schools \\ Dr. Loan Dao \\ Cancer Prevention Institute of California \\ Dr. Sophal Ear \\ U.S. Naval Postgraduate School \\ Dr. Samlong Inthaly \\ Minneapolis Public Schools \\ Dr. Kevin K. Kumashiro \\ University of Illinois, Chicago
}

\author{
Dr. Pollie Bith-Melander \\ Asian and Pacific Islander Wellness Center \\ Dr. George Chigas \\ University of Massachusetts, Lowell \\ Dr. Changming Duan \\ University of Missouri, Kansas City \\ Dr. Nancy H. Hornberger \\ University of Pennsylvania \\ Dr. Peter Nien-Chu Kiang \\ University of Massachusetts, Boston \\ Dr. Stacey Lee \\ University of Wisconsin, Madison
}


Vang - To Make A Return

\author{
Dr. David Chanpannha Ley \\ Montgomery County Public Schools \\ Dr. Bic Ngo \\ University of Minnesota \\ Dr. Leakhena Nou \\ California State University, Long Beach \\ Dr. Mark Pfeifer \\ Texas A\&M University, Corpus Christi \\ Dr. Bounlieng Phommasouvanh \\ Minnesota Department of Education \\ Dr. Kalyani Rai \\ University of Wisconsin, Milwaukee \\ Dr. Nancy J. Smith-Hefner \\ Boston University \\ Dr. Myluong Tran \\ San Diego State University \\ Dr. Linda Trinh Vo \\ University of California, Irvine \\ Dr. Zha Blong Xiong \\ University of Minnesota
}

\author{
Dr. Sue Needham \\ California State University, Dominguez Hills \\ Dr. Max Niedzwiecki \\ Daylight Consulting Group \\ Dr. Clara Park \\ California State University, Northridge \\ Dr. Loan T. Phan \\ University of New Hampshire \\ Dr. Karen Quintiliani \\ California State University, Long Beach \\ Dr. Fay Shin \\ California State University, Long Beach \\ Dr. Yer J. Thao \\ Portland State University \\ Dr. Khatharya Um \\ University of California, Berkeley \\ Dr. Zha Blong Xiong \\ University of Minnesota \\ Dr. Kou Yang \\ California State University, Stanislaus
}

\title{
Doctoral Student Editorial Review Board
}

\author{
Keo Chea-Young \\ University of Pennsylvania \\ Peter Tan Keo \\ Columbia University \\ Ravy Lao \\ University of California, Santa Barbara \\ Vanna Som \\ Harvard University \\ Layheng Ting \\ State University of New York, Albany \\ Tinou Tran \\ University of Houston, Texas
}

Annie BichLoan Duong

San Joaquin County Office of Education

\author{
Ha Lam \\ Arizona State University \\ Giang Pham \\ University of Minnesota
}

Rassamichanh Souryasack

University of California, Santa Barbara

Loan Tran

University of California, Santa Barbara

Phitsamay Sychitkokhong Uy Harvard University

Yang Sao Xiong

University of California, Los Angeles 